\title{
Biogenic and Metalic Element Accumulation in the European Perch (Perca fluviatilis) in the Largest Dam in Slovakia
}

\author{
Vladimír Hurta ${ }^{1,2 *}$, Zuzana Buchalová ${ }^{1}$ \\ ${ }^{1}$ Institute of High Mountain Biology, University of Žilina, Tatranská Javorina, Slovak Republic \\ ${ }^{2}$ Department of Ecology and Environmental Science, Faculty of Natural Sciences, \\ Constantine the Philosopher University in Nitra, Nitra, Slovak Republic
}

Received: 11 October 2017

Accepted: 18 January 2018

\begin{abstract}
Our study focuses on the European perch (Perca fluviatilis) regarding differences in concentrations of the biogenic ( $\mathrm{P}, \mathrm{S}, \mathrm{Cl}, \mathrm{K}, \mathrm{Ca}, \mathrm{Mn}, \mathrm{Zn})$ and metallic $(\mathrm{Sr}, \mathrm{Sb}, \mathrm{Rb}, \mathrm{Pb}, \mathrm{Mo}, \mathrm{Cr}, \mathrm{Fe}$ ) elements relative to perch morphology and environmental factors at the largest dam in Slovakia. The juvenile perch were sampled at four capture sites from June to October. The highest concentration of biogenic elements and metals was found in perch caught in the site disposed to wastewater effluent (WWE). The concentrations of biogenic elements in perch decrease with the size of the fish; at most the perch affected by WWE had the smallest size. The concentration of biogenic elements in perch increased with the date from June to October and with water temperature for all sites. Lead accumulated by the perch in all sites exceeded more than five times the maximum permissible limits provided by international institutions.
\end{abstract}

Keywords: heavy metal, biogenic elements, wastewater effluent, Perca fluviatilis

\section{Introduction}

Aquatic organisms are exposed to a complete mix of elements. The accumulation of elements in organisms often reflects the amount of these elements in the surrounding environment, especially in the water environment, where the elements are easily spread $[1,2]$. In studies where the concentration of metals in different lakes increased in gradient, the accumulation of metals increased in the juvenile perch transplanted up the gradient and the opposite down the gradient

*e-mail: vlad.hurta@gmail.com
[3]. The accumulation of elements in fish depends on environmental factors such as temperature, $\mathrm{pH}$, dissolve organic matter, and salinity [4-6]. These physicochemical parameters often change with the season, and thus season affects the bioavailability and accumulation of elements in fish [1]. Biological factors such as age, size, and weight of individuals, sex, reproduction cycle, feeding, and habitat use also play an important role in the accumulation of elements [2, 7-10]. The accumulation and the beneficial or toxic effects of elements depend on element properties. In general, elements are categorized into biologically essential and non-essential. Biogenic elements are integral components to support the function of an organism [11]. However, the concentration and accumulation of these elements account for the 
beneficial or harmful effects [11]. With respect to essential elements, there are symptoms of deficiency at low concentrations and toxicity at high concentrations. However, as to the nonessential elements, there is only the tolerance level [12]. Over the essential elements the fish have some homeostatic control, and their uptake and elimination is regulated by physiological mechanisms [11]. The non-essential elements are controlled by fish through acclimatization and detoxification [12]. They are detoxified to a certain threshold concentration by decreasing their uptake or by increasing their elimination rate [12]. But for fish chronically exposed to contaminants there is no threshold concentration, and chronic exposure to even a low concentration could yield stress and other adverse effects [3].

With the rising concentration of contaminants in water comes heightened toxicity for fish [11-13]. The toxicity of various elements has an effect on the structure and functionality of organs, and the endpoint is often connected with averse changes in survival, morphology, reproduction, and behaviour [11-12, 14]. Additionally, the majority of elements interact and actin synergy [1516]. Metals could even mimic the pathways of essential elements and thus inhibit their influx [12]. Fish are at the top of the food chain in fresh water and therefore they could accumulate the highest amount of elements [17]. So the accumulation of elements in fish could also determine the pollution of the whole ecosystem [14].

Waters affected by anthropogenic activities are a good source to study the effect of human development on the environment. The perch is widely distributed across the northern hemisphere in waters disposed to anthropogenic pressure. As a sedentary species and being relatively tolerant of environmental contaminants, in recent decades perch has attracted the attention of researchers [18]. They study the uptake and accumulation of inorganic and organic contaminants and their effects on perch - especially the investigation of metals. Anthropogenically driven metals, in comparison to natural ones, are released at a higher rate and make up half of all metal fluxes in the environment [19]. The concentration of metals in various tissues is studied, and often in relation to the accumulation, biometrics are measured [1]. The great source of nutrients, metals, and organic contaminants are wastewater treatment plants (WWTPs) [20-22]. Released municipal effluents cause eutrophication and the complete change of biota [23], and effects on the health of various fish species exposed to the wastewater contaminants were found [24-26]. Heavy metals present an especially serious threat to fish because of their long persistence, bioaccumulation, and biomagnification in the food chain [27].

The major aim of this research was to specify the influence of environmental and morphological factors on the accumulation of biogenic elements and metals in Perca fluviatilis. We also wanted to detect sites with potential contamination.

\section{Material and Methods}

\section{Study Area}

In 1975 , after the displacement of 4,000 people, the construction of the Liptovská Mara Dam $\left(49^{\circ} .06 \mathrm{~N}\right.$, $19^{\circ} .32 \mathrm{~N}$ ) in central Slovakia ended. Liptovská Mara is

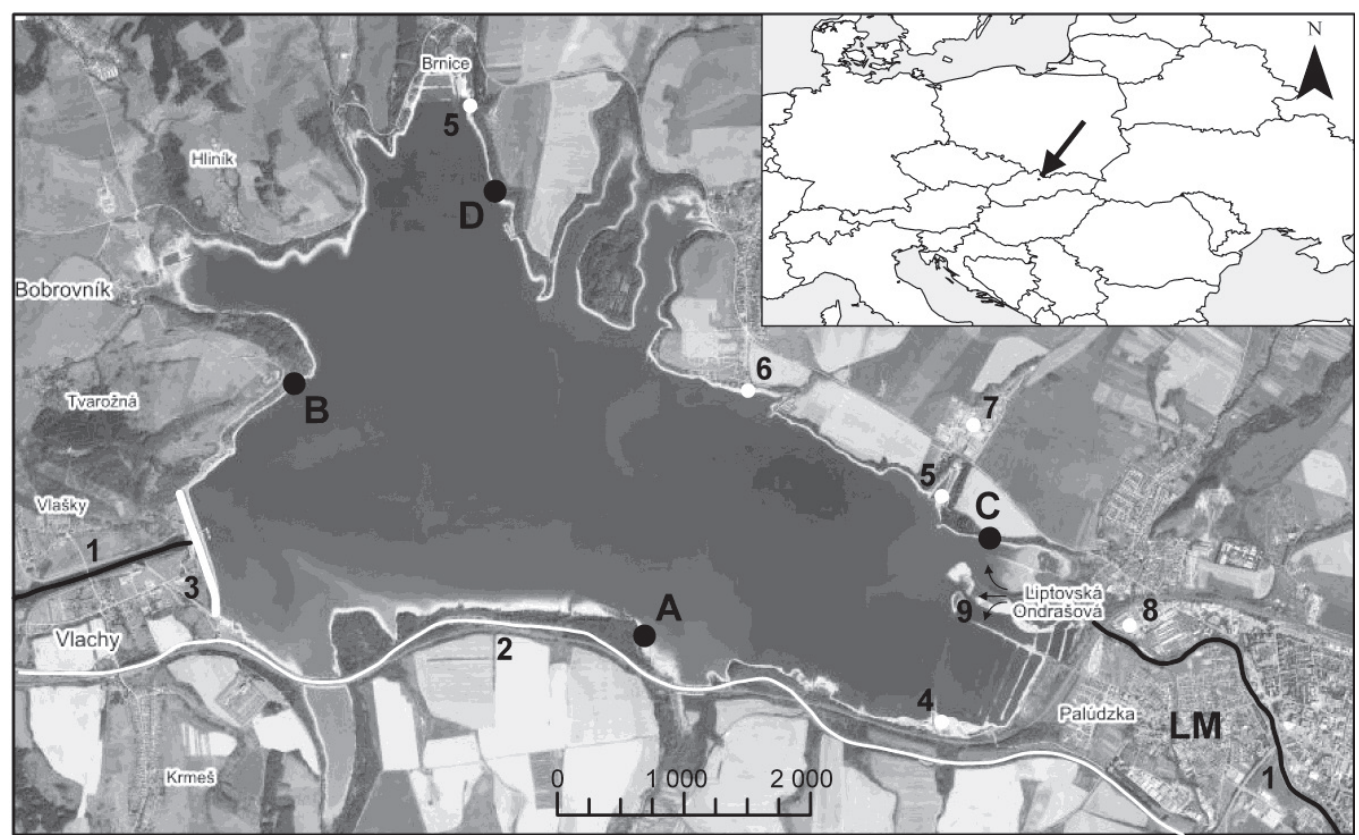

Fig. 1. Map of the study area: A-D represent capture sites, LM - the town Liptovský Mikuláš, 1 - river, 2 - highway, 3 - flood barrier, 4 - quarry, 5 - harbour, 6 - campsite, 7 - aquapark, 8 - wastewater treatment plant, 9 - wastewater effluent (source of aerial imagery: Eurosense 2015). 
the largest dam in Slovakia, with a volume of 361,9 mil. $\mathrm{m}^{3}$, an area of $21,6 \mathrm{~km}^{2}$, and maximum depth of $45 \mathrm{~m}$. The dam is home to about 30 fish species and a very popular holiday destination often called the "Slovakian Sea." This dam is also popular for recreational fishing. The eastern side is on the edge of the town of Liptovský Mikulás with a population of around 32,000. On the southern side, along the shore, there is a heavy traffic highway. The shore is bordered by groves, agriculture lands, and scattered small villages. The average temperature for the summer season (June-September) is $16,4^{\circ} \mathrm{C}$, and the average annual precipitation is $676,4 \mathrm{~mm}$. We determined four equally spaced fish capture sites (Fig. 1). The first site (A) is situated near the major highway. The next site (B) is situated in the fishing area - the same side as the dam barrier. The third site $(\mathrm{C})$ is near the town where the wastewater treatment plant (WWTP) is situated. Close to this site, there is a small harbour and a popular aquapark. The last site (D) is in a bay, which is also a very popular fishing area.

\section{Sample Collection}

The fish samples were collected from June to October 2016. We sampled juvenile ( $\leq 2$ years) Perca fluviatilis using a fishing rod with bait of bone worms. We also simultaneously used a dip fishing net (1x1 m) with bait of mixed breadcrumbs with strawberry aroma. The sampling interval was every fourteenth day from the beginning of June, so there were two samplings per month (except for October, when there was only one sampling day). On the sampling day we captured fish at all the sites. At every site we spent 90 minutes. We put each sample into an individual plastic bag marked with the number of the site, date, time, and air temperature. Air temperature was measured as an average of three measurements in 90 minutes at every site. Water temperature was acquired from the Slovak Aquaculture Company as an average per sampling day. After the sampling day, we transported the samples to the laboratory and measured the length and weight of every fish. Afterward the sample was frozen at $-40^{\circ} \mathrm{C}$.

\section{Sample Preparation}

After defrosting the sample at room temperature we put every fish in a Petri dish and dried the sample using a Memmert Universal Oven UF160 Plus. The time of drying was 12 hours at $75^{\circ} \mathrm{C}$ and $70 \%$ ventilation. We milled the dried sample using the CryoMill Retsch $\mathrm{GmbH} 2015$, and set the frequency of milling on 30/s; the time of milling was 2 minutes. For larger samples we set the milling time at 5 minutes with the same frequency. After the sample was milled we used X-ray fluorescence spectrochemical analysis with the XRF DELTA Classic spectrometer. The analysis was repeated three times and an average was calculated. Concentrations of the following elements were measured: $\mathrm{P}, \mathrm{S}, \mathrm{Cl}, \mathrm{K}, \mathrm{Ca}, \mathrm{Ti}$,
$\mathrm{Cr}, \mathrm{Mn}, \mathrm{Fe}, \mathrm{Co}, \mathrm{Ni}, \mathrm{Cu}, \mathrm{Zn}, \mathrm{As}, \mathrm{Se}, \mathrm{Rb}, \mathrm{Sr}, \mathrm{Zr}, \mathrm{Mo}, \mathrm{Ag}$, $\mathrm{Cd}, \mathrm{Sn}, \mathrm{Sb}, \mathrm{Ba}, \mathrm{Hg}$, and $\mathrm{Pb}$. The chemical elements were measured in $\mathrm{mg} \mathrm{kg}^{-1}$.

\section{Statistics}

The elements $\mathrm{Ti}, \mathrm{Co}, \mathrm{Ni}, \mathrm{Cu}, \mathrm{As}, \mathrm{Se}, \mathrm{Zr}, \mathrm{Ag}, \mathrm{Cd}$, $\mathrm{Sn}, \mathrm{Ba}$, and $\mathrm{Hg}$ were below the detection limit. All statistical analysis were conducted in IBM SPSS Statistics 23 using a critical value for each test set at $p=0.05$. Seven biogenic elements $(\mathrm{P}, \mathrm{S}, \mathrm{Cl}, \mathrm{K}, \mathrm{Ca}$, $\mathrm{Mn}$, and $\mathrm{Zn}$ ) with no missing data were selected for principal component analysis (PCA). The sample included 240 cases of juvenile Perca fluviatilis. We deleted two univariate outliers. The variables in the correlation matrix had all correlations above 0.7. The measure of sampling adequacy of every element was greater than 0.6, and the overall was 0.87. The Barlett Test of Sphericity was significant as well. We reran the PCA $(N=238)$ with varimax rotation. The PCA extracted only one component with eigenvalue greater than one. The single component had all loadings above 0.8 . The lowest communality was 0.75 . The single extracted component had a high positive correlation with all seven elements, which explained $81 \%$ of the variance.

A standard multiple regression was performed to identify the relationship between the morphometric and environmental factors and the accumulation of biogenic elements in Perca fluviatilis. The PCA component of biogenic elements was a response variable and the length of an individual, water temperature, air temperature, and date of a sample were used as predictors. The variables were measured at the scale level and had no missing values. The size and air temperature were log-transformed for normal distribution. Three univariate outliers in the biogenic elements and one in the size variable were deleted. The analysis was rendered with $N=234$.

To find the difference in the accumulation of biogenic elements between the four capture sites, multinomial logistic regression was applied on the dataset from PCA $(N=238)$. The response variable was the site (A-D), and the predictors were the length of an individual, air temperature, water temperature, date, and the PCA component of biogenic elements.

The elements $\mathrm{Sr}, \mathrm{Sb}, \mathrm{Rb}, \mathrm{Pb}, \mathrm{Mo}, \mathrm{Cr}$, and Fe had some amount of data below the detection limit. These elements were used to render a series of the separate one-way analysis of variance (ANOVA) to test the difference of element concentrations between the capture sites (A-D) with the Tukey post hoc. The outliers for elements $\mathrm{Sr}(4)$, $\mathrm{Cr}$ (4), and Fe (11) were deleted. The log-transformation of $\mathrm{Cr}$ and $\mathrm{Fe}$ was used for normal distribution. The Levenes test of homogeneity revealed unequal variances for $\mathrm{Fe}(\mathrm{F}(3,198)=3.43, \mathrm{p}=0.018)$ and for $\mathrm{Rb}(\mathrm{F}(3,234)=5.68, \mathrm{p}=0.001)$. We conducted Welch's ANOVA with the Games-Howell post hoc test for $\mathrm{Fe}$ and $\mathrm{Rb}$. 
Table 1. Mean concentrations (g.kg-1) of elements in the whole body mass of Perca fluviatilis in different capture sites (A-D).

\begin{tabular}{|c|c|c|c|c|c|c|}
\hline Element & $\mathrm{N}$ & $\mathrm{A}$ & $\mathrm{B}$ & $\mathrm{C}$ & $\mathrm{D}$ & Average \\
\hline $\mathrm{P}$ & 238 & $2.19 \pm 0.518$ & $2.081 \pm 0.606$ & $2.769 \pm 0.492$ & $2.16 \pm 0.646$ & $2.292 \pm 0.63$ \\
\hline $\mathrm{S}$ & 238 & $5.187 \pm 0.616$ & $5.01 \pm 0.795$ & $5.697 \pm 0.683$ & $4.931 \pm 0.794$ & $5.194 \pm 0.785$ \\
\hline $\mathrm{Cl}$ & 238 & $5.05 \pm 0.716$ & $5.039 \pm 1.029$ & $5.653 \pm 0.802$ & $4.788 \pm 0.965$ & $5.121 \pm 0.943$ \\
\hline $\mathrm{K}$ & 238 & $23.727 \pm 2.912$ & $22.765 \pm 3.399$ & $25.475 \pm 2.429$ & $21.972 \pm 3.206$ & $23.423 \pm 3.279$ \\
\hline $\mathrm{Ca}$ & 238 & $50.29 \pm 9.137$ & $49.525 \pm 11.841$ & $60.022 \pm 7.679$ & $52.825 \pm 13.449$ & $53.104 \pm 11.569$ \\
\hline $\mathrm{Mn}$ & 238 & $0.035 \pm 0.01$ & $0.032 \pm 0.013$ & $0.051 \pm 0.013$ & $0.035 \pm 0.010$ & $0.038 \pm 0.014$ \\
\hline $\mathrm{Zn}$ & 238 & $0.227 \pm 0.054$ & $0.205 \pm 0.061$ & $0.261 \pm 0.034$ & $0.203 \pm 0.061$ & $0.223 \pm 0.059$ \\
\hline $\mathrm{Sr}$ & 236 & $0.079 \pm 0.012$ & $0.08 \pm 0.013$ & $0.087 \pm 0.012$ & $0.08 \pm 0.012$ & $0.081 \pm 0.013$ \\
\hline $\mathrm{Sb}$ & 104 & $0.013 \pm 0.002$ & $0.012 \pm 0.002$ & $0.014 \pm 0.002$ & $0.013 \pm 0.002$ & $0.013 \pm 0.002$ \\
\hline $\mathrm{Rb}$ & 238 & $0.025 \pm 0.004$ & $0.023 \pm 0.004$ & $0.028 \pm 0.003$ & $0.021 \pm 0.005$ & $0.024 \pm 0.005$ \\
\hline $\mathrm{Pb}$ & 165 & $0.008 \pm 0.002$ & $0.007 \pm 0.002$ & $0.008 \pm 0.002$ & $0.007 \pm 0.002$ & $0.008 \pm 0.002$ \\
\hline $\mathrm{Mo}$ & 230 & $0.004 \pm 0.001$ & $0.003 \pm 0.001$ & $0.004 \pm 0.001$ & $0.003 \pm 0.001$ & $0.004 \pm 0.001$ \\
\hline $\mathrm{Cr}$ & 197 & $0.009 \pm 0.003$ & $0.008 \pm 0.004$ & $0.013 \pm 0.005$ & $0.009 \pm 0.003$ & $0.01 \pm 0.004$ \\
\hline $\mathrm{Fe}$ & 202 & $0.131 \pm 0.084$ & $0.138 \pm 0.108$ & $0.279 \pm 0.148$ & $0.184 \pm 0.125$ & $0.183 \pm 0.132$ \\
\hline
\end{tabular}

\section{Results}

The mean concentrations of fourteen elements in the whole body mass of Perca fluviatilis are given in Table 1. The standard multiple regression revealed that there is a significant relationship between the concentration of biogenic elements $(\mathrm{P}, \mathrm{S}, \mathrm{Cl}, \mathrm{K}, \mathrm{Ca}, \mathrm{Mn}$, $\mathrm{Zn})$ in perch and the length of the perch, water and air temperature, and date $(F(4,229)=45.22, p<0.001$, with $R^{2}$ at $0.44(95 \% \mathrm{CI}=0.35$ to 0.53$)$, adjusted $\left.\mathrm{R}^{2}=0.43\right)$. Altogether, $44 \%$ of the variability in concentrations of biogenic elements was predicted by the length of the perch, water and air temperatures, and date. The four predictors in combination contributed only 0.03 in the shared variability, and the unique variability was 0.41 . The size and direction of relationships suggest that the accumulation of biogenic elements is decreasing with the length of fish and increasing with the air and water temperature (Table 2). In addition, the accumulation increases with the date from June to October. The length of fish $\left(s r^{2}=0.31\right)$ is the most important predictor, and the other three predictors explain a very small proportion of variance.

The multinomial logistic regression revealed a significant relationship between the four capture sites (A-D) and the length of the perch, air and water temperature, date, and the concentration of biogenic elements in the perch (Deviance $\chi^{2}=, \alpha=0.999$, Pearson $\chi^{2}=, \alpha=0.384$; correct overall classification $=43,3 \%, \mathrm{~A}=7,3 \%, \mathrm{~B}=43,5 \%, \mathrm{C}=75,4 \%, \mathrm{D}=45,3 \%$; $\mathrm{R}=0.295(95 \% \mathrm{CI}=0.16,0.36)$. The length of the perch and the concentration of biogenic elements significantly distinguish the four categories of capture sites. Perch caught at site D had the largest size, followed by the perch at sites A and B; the smallest were caught at site $\mathrm{C}$. Among all the sites, perch caught at site $\mathrm{C}$ had the highest concentrations of biogenic elements (Table 3).

Table 2. Results of multiple regression with biogenic element (P, S, Cl, K, Ca, Mn, Zn) concentrations in Perca fluviatilis grouped in one principal component as a response variable and four predictors; log transformation of fish length (Length_log), water temperature, log transformation of air temperature (Air temp. log), and date of capture.

\begin{tabular}{|c|c|c|c|c|c|c|}
\hline Predictor & $\beta$ & Std. Error & OR & $\mathrm{t}$ & $95 \%$ CI & $s r^{2}$ (unique) \\
\hline Constant & 0.457 & .957 & & .478 & $-1.428,2.342$ & \\
\hline Length_log & $-4.877^{* *}$ & .431 & -.568 & -11.325 & $-5.726,-4.029$ & 0.31 \\
\hline Water temp. & $0.098^{*}$ & .035 & .174 & 2.813 & $0.029,0.167$ & 0.02 \\
\hline Air temp._log & $0.412^{*}$ & .144 & .168 & 2.868 & $0.129,0.695$ & 0.02 \\
\hline Date & $0.007^{* *}$ & .001 & .301 & 5.641 & $0.005,0.01$ & 0.08 \\
\hline
\end{tabular}

$* p<0.05, * * p<0.001$. 
Table 3. Results of the multinomial logistic regression comparing the four categories (A-D) of the response variable capture site from the predictors; fish length (Length) and concentrations of biogenic elements (P, S, Cl, K, Ca, Mn, Zn) in Perca fluviatilis were grouped in one principal component (Bio_elements).

\begin{tabular}{|c|c|c|c|c|c|c|}
\hline Predictor & Comparison of sites & $\beta$ & SE & Wald & OR & $95 \%$ CI OR \\
\hline Length & $A$ vs $D^{a}$ & $-0.246^{*}$ & 0.12 & 4.177 & 0.782 & $0.62,0.99$ \\
\hline Bio_elements & A vs $D^{a}$ & -0.055 & 0.273 & 0.04 & 0.947 & $0.55,1.62$ \\
\hline Length & $\mathrm{B}$ vs $\mathrm{D}^{\mathrm{a}}$ & $-0.219^{*}$ & 0.112 & 3.840 & 0.803 & $0.65,1$ \\
\hline Bio_elements & $\mathrm{B}$ vs $\mathrm{D}^{\mathrm{a}}$ & -0.271 & 0.274 & 0.975 & 0.763 & $0.45,1.31$ \\
\hline Length & $\mathrm{C}$ vs $\mathrm{D}^{\mathrm{a}}$ & $-0.86 * *$ & 0.206 & 17.420 & 0.423 & $0.23,0.63$ \\
\hline Bio_elements & $\mathrm{C}$ vs $\mathrm{D}^{\mathrm{a}}$ & $0.759^{*}$ & 0.294 & 6.683 & 2.136 & $1.2,3.8$ \\
\hline Length & A vs $C^{a}$ & $0.614 *$ & 0.205 & 8.994 & 1.848 & $1.24,2.76$ \\
\hline Bio_elements & A vs $C^{a}$ & $-0.814^{*}$ & 0.29 & 7.868 & 0.443 & $0.25,0.78$ \\
\hline Length & $\mathrm{B}$ vs $\mathrm{C}^{\mathrm{a}}$ & $0.641^{*}$ & 0.204 & 9.909 & 1.898 & $1.27,2.83$ \\
\hline Bio_elements & $\mathrm{B}$ vs $\mathrm{C}^{\mathrm{a}}$ & $-1.030 * *$ & 0.301 & 11.714 & 0.357 & $0.2,0.64$ \\
\hline Length & A vs B ${ }^{a}$ & -0.027 & 0.121 & 0.049 & 0.974 & $0.77,1.23$ \\
\hline Bio_elements & $A$ vs $B^{a}$ & 0.216 & 0.28 & 0.595 & 1.241 & $0.72,2.15$ \\
\hline
\end{tabular}

$* p \leq 0.05,{ }^{*} p \leq 0.001 ;{ }^{a}$ the reference category

ANOVA results showed that perch caught at site $\mathrm{C}$ had the highest concentrations of $\mathrm{Sr}$ among all the sites $(\mathrm{F}(3,232)=5.109, \mathrm{p}=0.002)$. Perch at site $\mathrm{C}$ had higher concentrations of $\mathrm{Sb}$ than perch in site $\mathrm{B}$ $(F(3,100)=3.004, p=0.034)$. Perch in site $C$ had higher concentrations of $\mathrm{Pb}$ relative to sites $\mathrm{B}$ and $\mathrm{D}$ $(\mathrm{F}(3,161)=4.413, \mathrm{p}=0.005)$. Perch in site $\mathrm{C}$ had higher concentrations of $\mathrm{Cr}$ among all the sites $(\mathrm{F}(3,193)=15.442$, $\mathrm{p}<0.001)$. Perch in site $\mathrm{C}$ had higher concentrations of $\mathrm{Fe}$ among all the sites $(\mathrm{F}(3,108.89)=18.687, \mathrm{p}<.001)$. Perch in site $\mathrm{C}$ had higher concentrations of $\mathrm{Rb}$ among all the sites, and perch in site $\mathrm{A}$ had higher concentrations of $\mathrm{Rb}$ relative to sites $\mathrm{B}$ and $\mathrm{D}(\mathrm{F}(3,128.86)=37.496, \mathrm{p}<.001)$. Perch in sites $\mathrm{A}$ and $\mathrm{C}$ had higher concentrations of $\mathrm{Mo}$ relative to sites $\mathrm{B}$ and $\mathrm{D}(\mathrm{F}(3,226)=13.736, \mathrm{p}<.001)$ (Table 4).

\section{Discussion}

The size difference of perch between the capture sites was observed. The perch at site $\mathrm{D}$ had the greatest size, followed by the perch at the sites A and B, and the smallest perch were at site $\mathrm{C}$. This diversification could be due to phenotypic plasticity and genetic variation. Genetic studies of the perch in the last twenty years have suggested that perch within one lake do not form a single panmictic population, but create genetically different subpopulations $[28,29]$. Yet in small-scale waters there exist some cryptic barriers to dispersal [28]. The genetic differences between subpopulations correlate with the changes in environmental parameters, such as the temperature at time of spawning [30]. The other cause of differentiation into subpopulations could be a philopathric behavior to spawning sites, kin recognition, and kin preference [31, 32]. The morphometric difference in size may suggest the existence of three subpopulations in the dam. If individuals are philopatric to the capture site and create subpopulations, we can assume that a different accumulation of elements between sites is a manifestation of local and diversified environmental chemistry in the dam.

Site C, with the smallest perch, correspond with the highest accumulation of biogenic elements grouped in one component $(\mathrm{P}, \mathrm{S}, \mathrm{Cl}, \mathrm{K}, \mathrm{Ca}, \mathrm{Mn}, \mathrm{Zn})$ and other elements ( $\mathrm{Sr}, \mathrm{Sb}, \mathrm{Pb}, \mathrm{Cr}, \mathrm{Fe})$ between all sites. This site also relates to the greatest amount of pollutant sources. To the west of this site lie the aquapark and the harbour $(250 \mathrm{~m})$, while to the east there is the edge of the urban area $(250 \mathrm{~m})$ where the WWTP is located. The purified wastewater is discharged into the river, which flows into the dam. The river current is diffused almost directly in the area of this site. The source of contamination could also be the agricultural land that borders the shore. Agricultural lands are often responsible for excess emissions of nutrients and metals [33, 34]. Higher concentrations of biogenic elements and contaminants in fish exposed to wastewater effluent (WWE) is commonly reported $[25,35,36]$. WWE mainly increases the input of nutrients in fresh water [22]. The fish exposed to the wastewater contamination derive part of their nutrition from these effluents [35]. As the smallest perch were captured in this site, we assume some chronic effects of elevated concentrations of contaminants on perch growth. WWE is a mixture of environmental contaminants, and its discharge may lead to a complex change of aquatic biota [23,37]. Endocrine disruptive chemicals, ammonia, and metals are present in WWE 
Table 4. Post-hoc comparisons (ANOVA) of the concentrations of $\mathrm{SR}, \mathrm{Sb}, \mathrm{Pb}, \mathrm{Cr}, \mathrm{Fe}, \mathrm{Rb}$, and $\mathrm{Mo}$ in Perca fluviatilis between the capture sites (A-D).

\begin{tabular}{|c|c|c|c|c|c|}
\hline Element & $N$ & Comparison of sites & Mean accumulation difference & Std. Error & $95 \% \mathrm{CI}$ \\
\hline $\mathrm{Sr}^{\mathrm{a}}$ & 236 & C vs A & $7.9560^{*}$ & 23.553 & $1.86,14.05$ \\
\hline $\mathrm{Sr}^{\mathrm{a}}$ & 236 & C vs B & $7.0834^{*}$ & 22.837 & $1.17,12.99$ \\
\hline $\mathrm{Sr}^{\mathrm{a}}$ & 238 & C vs D & $6,9707^{*}$ & 22.746 & $1.09,12.86$ \\
\hline $\mathrm{Sb}^{\mathrm{a}}$ & 104 & C vs B & $1.688^{*}$ & 0.58 & $0.17,3.2$ \\
\hline $\mathrm{Pb}^{\mathrm{a}}$ & 165 & C vs B & $1.125^{*}$ & 0.428 & $0.01,2.24$ \\
\hline $\mathrm{Pb}^{\mathrm{a}}$ & 165 & C vs D & $1.290^{*}$ & 0.448 & $0.13,2.45$ \\
\hline Cr_log ${ }^{a}$ & 197 & C vs A & $0.13298^{* *}$ & 0.03205 & $0.05,0.22$ \\
\hline Cr_loga & 197 & C vs B & $0.20361^{* *}$ & 0.03242 & $0.12,0.29$ \\
\hline Cr_log ${ }^{a}$ & 197 & C vs D & $0.16464^{* *}$ & 0.03223 & $0.08,0.25$ \\
\hline $\mathrm{Fe} \_\log ^{\mathrm{b}}$ & 202 & $\mathrm{C}$ vs A & $0.32494^{* *}$ & 0.04856 & $0.2,0.45$ \\
\hline $\mathrm{Fe} \_\log ^{\mathrm{b}}$ & 202 & C vs B & $0.35950^{* * *}$ & 0.0588 & $0.21,0.51$ \\
\hline $\mathrm{Fe} \_\log ^{\mathrm{b}}$ & 202 & C vs D & $0.21460^{* *}$ & 0.05521 & $0.07,0.36$ \\
\hline $\mathrm{Rb}^{\mathrm{b}}$ & 238 & A vs B & $2.3179^{*}$ & 0.7019 & $0.49,4.15$ \\
\hline $\mathrm{Rb}^{\mathrm{b}}$ & 238 & A vs D & $4.326^{* *}$ & 0.8305 & $2.16,6.49$ \\
\hline $\mathrm{Rb}^{\mathrm{b}}$ & 238 & C vs A & $2.9713^{* *}$ & 0.6740 & $1.21,4.73$ \\
\hline $\mathrm{Rb}^{\mathrm{b}}$ & 238 & C vs B & $5.2892^{* * *}$ & 0.6433 & $3.61,6.97$ \\
\hline $\mathrm{Rb}^{\mathrm{b}}$ & 238 & C vs D & $7.2973^{* *}$ & 0.7817 & $5.26,9.34$ \\
\hline $\mathrm{Mo}^{\mathrm{a}}$ & 230 & A vs B & $0.53372^{*}$ & 0.19796 & $0.02,1.05$ \\
\hline $\mathrm{Mo}^{\mathrm{a}}$ & 230 & A vs D & $0.75987^{* *}$ & 0.19478 & $0.26,1.26$ \\
\hline $\mathrm{Mo}^{\mathrm{a}}$ & 230 & C vs B & $0.88494^{* *}$ & 0.19443 & $0.38,1.39$ \\
\hline $\mathrm{Mo}^{\mathrm{a}}$ & 230 & C vs D & $1.11108^{* *}$ & 0.19119 & $0.62,1.61$ \\
\hline
\end{tabular}

$* p \leq 0.05, * * p \leq 0.001 ;{ }^{\mathrm{a} T u k e y ~ H S D ~ t e s t, ~}{ }^{\mathrm{b}}$ Game-Howell test.

[38-40]. These contaminants were proven to affect the growth of fish [41, 42]. Tetreault [25] reported longer white stickleback collected downstream of the WWTP, but fatheads from the same site were shorter. Generally increased condition and growth is referred to fish exposed to WWE [26, 43, 44]. The increase in fish condition is explained by the enhanced productivity of waters affected by urban effluents [37]. However, the enhance growth refers mainly to older fish classes [26, 43, 44]. In juveniles, the toxic effect may have a greater impact than the benefits of nutrient enlargement [45]. WWE often contains a variety of metals $[37,40,46]$.

Many studies have shown reduced growth in fish exposed to metal contaminants [11, 12, 47]. Pyle et al. [48] studied yellow perch in lakes with the metal contamination gradient. The perch grew slower along the gradient of high concentration. The reduced growth was reported for contamination of $\mathrm{Pb}, \mathrm{Fe}, \mathrm{Cr}, \mathrm{Zn}, \mathrm{Sb}, \mathrm{P}$, and $\mathrm{Cl}$ [47, 49-54]. Fish studies recognize direct effects of elements on fish growth and indirect effects through the negative impact on the food web and habitat [11, 12]. The direct effects of metals on bioenergetics of fish could potentially reduce growth. Metals were reported to reduce aerobic and biosynthetic capacity, feeding activity, swimming speed, and resting $[18,55]$. Metals increase energy demands, metabolic cost, and impair the endocrine functions [55-57]. The metabolic rate of fish in metal-contaminated waters tends to decrease [55], which could lead to lower uptake of mass and smaller size of fish in the most contaminated site. Fish exposed to metal contaminants try to reduce the impact through detoxification $[11,12]$, which should be reflected by the reduction of growth [58]. Some indirect factors could be responsible for the smaller individuals in the most exposed site. Fish exposed to metal contamination exhibit delayed spawning and delayed hatching [12, 59]. The delayed spawning is referred also to fishes exposed to WWE [25]. Metal contamination could also result in a change of habitat use, predator-prey interactions, and competition with subsequent changes in fish morphology $[11,60,61]$. The attribution of reduced growth could be due to decrease diversity and abundance of invertebrates as a response to metal contamination [62].

We found higher concentrations of biogenic elements in smaller individuals. Biogenic elements are structural components of enzymes, and enzymes such 
as nucleoside diphosphokinase were associated with fish growth [63]. Most of the biogenic elements grouped in one component were metals $(\mathrm{Cl}, \mathrm{K}, \mathrm{Ca}, \mathrm{Mn}, \mathrm{Zn})$. Many studies found higher concentrations of biogenic metals in smaller fish [1, 64]. For the negative relationship between metal concentrations and growth, the difference in metabolic activity between younger and older fish could be responsible [64]. Younger, smaller fish, due to their excessive growth, development, and higher metabolic rate, have higher energy requirements and thus need to accumulate higher amounts of biogenic elements. Younger individuals have higher uptake of elements and older one have a higher elimination rate. [1]. The juveniles are also more sensitive (especially to heavy metals) than the mature stages $[45,65]$. Various metals show different bioconcentrations in accordance with metal properties and the properties of target tissue [11, 12]. Liang et al. [66] found that the hepatic $\mathrm{Cu}$ concentrations in several fish species decreased with the size of the fish, the contrary hepatic $\mathrm{Zn}$ concentration increased with the size of the fish, but the $\mathrm{Zn}$ content in the muscles decreased. Such differences in concentrations of metals in relation to fish growth are commonly reported even for one element. Başyğit and Tekin-Özan [1] determined a positive relationship between fish weight and Mn levels in muscles and gills, and a negative relationship between fish length and Mn levels in the liver and gills. Fish accumulate most of the metals in the metabolically active tissues like liver and gills [67, 68]. The concentrations of heavy metals in gills and liver tends to increase with age and size of the fish [2], but the muscles proved to be an inactive tissue and the metals there are degrading $[67,69]$. In our study, we did not use individual organs for analysis, but the whole body mass - and therefore muscles - was the most important part in the resulting concentration.

There was a higher accumulation of biogenic elements during the sampling time, and the concentration was increasing from June to October. Seasonal variations in the concentrations of metals and biogenic elements are commonly reported [1, 70-72]. These elements often do not vary together, and there are seasonally different peaks and falls for different elements [71]. Many causes have been demonstrated to affect seasonal tissue element concentrations. Diet-borne concentration of elements in fish is changing with food diversity, food abundance, change in diet, and feeding rate $[11,72,73]$. Yellow perch tissue metal concentration peaked in summer with the increase in food uptake [74]. Kraemer et al. [75] reported seasonal variations in the hepatic $\mathrm{Cu}$ concentration in yellow perch. As the perch change diet during the season, the tissue concentration decreased, but the total burden increased. The biogenic elements concentrations in fish often reflect the ambient concentrations of these elements in water $[72,76]$. The concentration of elements in the water column depends on physicochemical parameters such as temperature and dissolved organic matter, and these parameters influence the bioavailability of elements across the season $[77,78]$. Thus the abiotic factors like the photoperiod indirectly affect the accumulation of elements in fish [79].

We have statistically found that the accumulation of biogenic elements in perch increased with water temperature. The highest temperature in the dam was from July to September. Higher temperature in summer tends to raise $\mathrm{pH}$, evaporation, photosynthesis, conductivity, and inorganic substances, and decrease $\mathrm{CO}_{2}$ [80]. These changing parameters influence the bioavailability of biogenic elements. Most of the studies report the highest concentrations of biogenic elements in fish in the summer, and they mostly relate these concentrations to water temperature [59, 71, 81, 82]. Fish with increasing ambient temperatures increase their metabolic rate [83]. Zayed and Eldien [81] found the highest metal contents in fish during the summer, which suggested that it was due to a higher rate of breathing and lower oxygen content in water. The metabolic rate was responsible for the highest concentrations of $\mathrm{Cd}, \mathrm{Cu}$, $\mathrm{Pb}, \mathrm{Fe}$, and $\mathrm{Zn}$ during the summer in marine fish [82]. Also, the growth rate of perch is highest in summer and therefore the perch could demand higher amounts of nutrients [84]. The precipitation was reported as being responsible for the highest concentrations of tissue metal during the wet season in various fish species $[85,86]$. The highest precipitation in the area of the dam were in July and August. Precipitation could splash the biogenic elements from surrounding agricultural lands, and thus elevate their content in the dam. Also, the amount of water flow could affect the element concentrations in the dam. Johansson et al. [87] reported the increased metal concentrations in the lake during the rainy season due to high precipitation and high river flooding. The discharge of the river feeding the dam was highest in the summer. The other factors affecting the tissue element concentrations could be the population activities as reproduction. Mzimela et al. [88] found low values in hepatic $\mathrm{Zn}$ concentrations during spawning, followed by an increase during the post-spawning season. For the European perch, the spawning season ends in June and even the one-year-old perch could associate in spawning [18]. The lowest concentrations of biogenic elements in perch in the dam were found in the middle of June (following the increase in July), and the highest concentrations were in September and October. We suggest that the biogenic element concentrations in the perch cumulate over the summer and thus reach the highest concentrations in the whole body mass in autumn. Başyiğit [1] found the highest concentrations of biogenic elements in the muscle of pikeperch in autumn. These highest concentrations could be induced by various environmental factors and biological factors of the perch, acting in synergy.

From the studied elements, the maximum permissible levels are set only for $\mathrm{Pb}$. According to the European Commission (EC), the Food and Agriculture Organization of the United Nations (FAO), and the World Health Organization (WHO), the maximum level for $\mathrm{Pb}$ in fish for human consumption is $0.3 \mathrm{mg} / \mathrm{kg}$ of wet weight $[89,90]$. In order to compare the data obtained in this 
study with prescribed limits, concentrations of $\mathrm{Pb}$ were recalculated to wet weight according to the conversion factor of 0.246 for Perca fluviatilis [91]. Concentrations of $\mathrm{Pb}$ in wet weight were $1.968 \mathrm{mg} / \mathrm{kg}$ in sites $\mathrm{A}$ and $\mathrm{C}$, and 1.722 in sites $\mathrm{B}$ and $\mathrm{D}$. The concentrations of $\mathrm{Pb}$ in perch highly exceeded the limit.

\section{Conclusions}

This study was carried out to provide information on biogenic and metal element concentrations in Perca fluviatilis. As expected, the highest concentrations of biogenic elements and metals were found in perch caught in the site disposed to WWE. This site also saw the smallest perch captured, and higher concentrations of biogenic elements were found in smaller individuals. The concentrations of biogenic elements increased from June to October, corresponding to increased water temperature. Regular monitoring of heavy metal concentrations should be conducted in the future since the levels of $\mathrm{Pb}$ exceeded the limit values for fish in all sampling sites.

\section{Acknowledgements}

We would like to thank Prof. Marián Janiga for helpful comments. We thank Mário Václavík for field assistance and Dr. Dalibor Mikuláš for grammatical correction of the manuscript.

\section{Conflict of Interest}

The authors declare no conflict of interest.

\section{References}

1. BAȘYIĞIT B., TEKIN-ÖZAN S. Concentrations of some heavy metals in water, sediment, and tissues of pikeperch (Sander lucioperca) from Karataş lake related to physicochemical parameters, fish size, and seasons. Pol. J. Environ. Stud. 22 (3), 633, 2013.

2. KASIMOGLU C. The effect of fish size, age and condition factor on the contents of seven essential elements in Anguilla Anguilla from Tersakan stream Mugla (Turkey). J. Pollut. Eff. Cont. 2 (2), 2014.

3. GIGUÈRE A., CAMPBELL P.G.C., HARE L., COUTURE P. Sub-cellular partitioning of cadmium, copper, nickel and zinc in indigenous yellow perch (Perca flavescens) sampled along a polymetallic gradient. Aquat. Toxicol. 77 (2) 178, 2006.

4. SASSI A., ANNABI A., KESSABI K., KERKENI A., SAÏD K., MESSAOUDI I. Influence of high temperature on cadmium-induced skeletal deformities in juvenile mosquitofish (Gambusia affinis) Fish Physiol Biochem. 36 (3), 403, 2010.

5. BIELMYER G. K., BULLINGTON J. B., DECARLO C. A., CHALK S. J., SMITH K. The effects of salinity on acute toxicity of zinc to two euryhaline species of fish, Fundulus heteroclitus and Kryptolebias marmoratus. Integr. Comp. Biol. 52 (6), 753, 2012.

6. QUELLET J.D., DUBÉ M.G., NIVOGI S. Influence of elevated alkalinity and natural organic matter (NOM) on tissue-specific metal accumulation and reproductive performance in fathead minnows during chronic, multitrophic exposures to a metal mine effluent. Ecotoxicol. Environ. Saf. 95, 104, 2013.

7. PODRUG M., RASPOR B. Seasonal variation of the metal ( $\mathrm{Zn}, \mathrm{Fe}, \mathrm{Mn})$ and metallothionein concentrations in the liver cytosol of the European chub (Squalius cephalus L.). Environ. Monit. Assess. 157 (1-4) 1, 2009.

8. WOOD C.M., GROSELL M., MCDONALD D.M., PLAYLE R.C., WALSH P.J. Effects of waterborne silver in a marine teleost, the gulf toadfish (Opsanus beta): effects of feeding and chronic exposure on bioaccumulation and physiological responses. Aquat. Toxicol. 99 (2), 138, 2010.

9. RAJKOWSKA M., PROTASOWICKI M. Distribution of metals ( $\mathrm{Fe}, \mathrm{Mn}, \mathrm{Zn}, \mathrm{Cu}$ ) in fish tissues in two lakes of different trophy in Northwestern Poland. Environ. Monit. Assess. 185 (4), 3493, 2013.

10. WEBER P., BEHR E.R., KNORR C.D.L., VENDRUSCOLO D.S., FLORES E.M.M. DRESSLER V.L., BALDISSEROTTO B. Metals in the water, sediment, and tissues of two fish species from different trophic levels in a subtropical Brazilian river. Microchem. J. 106, 61, 2013.

11. WOOD C., FARRELL A., BRAUNER C. Homeostasis and Toxicology of Essential Metals 31A. 1st ed.; Academic Press. 2012.

12. WOOD C., FARRELL A., BRAUNER C. Homeostasis and Toxicology of Non-Essential Metals 31B. $1^{\text {st }}$ ed.; Academic Press. 2012.

13. GIARDINA A., LARSON S.E., WISNER B., WHEELER J., CHAO M. Long-term and acute effects of zinc contamination of a stream on fish mortality and physiology. Environ. Toxicol. Chem. 28 (2), 287, 2009.

14. AUTHMAN M.N., ZAKI M.S., KHALLAF E.A., ABBAS H.H. Use of Fish as Bio-indicator of the Effects of heavy metals pollution. J. Aquac. Res. Development. 6 (4), 328, 2015.

15. NIYOGY S., NADELLA S.R., WOOD C.M. Interactive effects of waterborne metals in binary mixtures on shortterm gill-metal binding and ion uptake in rainbow trout (Oncorhynchus mykiss). Aquat. Toxicol. 165, 109, 2015.

16. SAULIUTÉ G., SVECEVIČIUS G. Heavy metal interactions during accumulation via direct route in fish. Zoo. Eco. 25 (1), 77, 2015.

17. WARD D.M., NISLOW K.H., FOLT C.L. Bioaccumulation syndrome: identifying factors that make some stream food webs prone to elevated mercury bioaccumulation Ann. N Y Acad. Sci. 1195, 62, 2010.

18. COUTURE P., PYLE G. Biology of Perch. $1^{\text {st }}$ ed.; CRC press. 2015.

19. RAUCH J.N., PACYNA J.M. Earth's global Ag, Al, $\mathrm{Cr}, \mathrm{Cu}$, $\mathrm{Fe}, \mathrm{Ni}, \mathrm{Pb}$, and $\mathrm{Zn}$ cycles. Global Biogeochem. Cycles. 23 (2), 2009.

20. CAREY R.O., MIGLIACCIO K.W. Contribution of wastewater treatment plant effluents to nutrient dynamics in aquatic systems: a review. Environ. Manag. 44 (2), 205, 2009.

21. BARCO-BONILLA N., ROMERO-GONZÁLEZ R., PLAZA-BOLAÑOS P., MARTÍNEZ VIDAL J.L. CASTRO A.J., MARTÍN I., SALAS J.J., FRENICH A.G. Priority organic compounds in wastewater 
effluents from the Mediterranean and Atlantic basins of Andalusia (Spain). Environ. Sci. Process Impacts. 15 (12), 2194, 2013.

22. GONG D., GAO X., NTAKIRUTIMANA T., GUO J., LI K. Water quality status along the Liangtan River and control planning alternatives for pollution reduction. Pol. J. Environ. Stud. 22 (4), 1061, 2013.

23. KIEDRZYŃSKA E., KIEDRZIŃSI M., URBANIAK M., MAGNUSZEWSKI A., SKŁODOWSKI M., WYRWICKA A., ZALEWSKI M. Point sources of nutrient pollution in the lowland river catchment in the context of the Baltic Sea eutrophication. Ecol. Eng. 70, 337, 2014.

24. CAZENAVE J., BACCHETTA C., ROSSI A., ALE A., CAMPANA M., PARMA M.J. Deleterious effects of wastewater on the health status of fish: A field caging study. Eco. Indic. 38, 104, 2014

25. TETREAULT G.R. The Response of Wild Fish to Municipal Wastewater Effluent Exposures at Sites in Canada. PhD thesis. University of Waterloo, Waterloo, Canada. 2012

26. ARCISZEWSKI T.J., KIDD T.J., MUNKITTRICK K.R. Comparing responses in the performance of sentinel populations of stoneflies (Plecoptera) and Slimy Sculpin (Cottus cognatus) exposed to enriching effluents. Ecotoxicol. Environ. Saf. 74 (7), 1844, 2011.

27. Y Y., TANG C., T Y., YANG Z., ZHANG S. Health risk assessment of heavy metals in fish and accumulation patterns in food web in the upper Yangtze River, China. Ecotoxicol. Environ. Saf. 145, 295, 2017.

28. BERGEK S., OLSSON J. Spatiotemporal analysis shows stable genetic differentiation and barriers to dispersal in the Eurasian perch (Perca fluviatilis L.). Evol. Ecol. Res. 11, 827, 2009.

29. KOCOVSKY P.M., SULLIVAN T.J., KNIGHT C.T. STEPIEN C.A. Genetic and morphometric differences demonstrate fine-scale population substructure of the yellow perch Perca flavescens: need for redefined management units. J. Fish Biol. 82 (6), 2015, 2013.

30. BERGEK S., SUNDBLAD G., BJÖRKLUND M. Population differentiation in perch Perca fluviatilis: environmental effects on gene flow? J. Fish Biol. 76 (5), 1159, 2010.

31. SEPULVEDA-VILLET O.J., STEPIEN C.A. Fine-scale population genetic structure of the yellow perch Perca flavescens in Lake Erie. Can. J. Fish. Aquat. Sci. 68, 1435, 2011.

32. SULLIVAN T.J., STEPIEN C.A. Genetic diversity and divergence of yellow perch spawning populations across the Huron-Erie Corridor, from Lake Huron through western Lake Erie. J. Great Lakes Res. 40 (2), 101, 2014.

33. LI J., LI F., LIU Q., ZHANG Y. Trace metal in surface water and groundwater and its transfer in a Yellow River alluvial fan: Evidence from isotopes and hydrochemistry. Sci. Total Environ. 475, 979, 2014.

34. STROKAL M., MA L., BAI Z., LUAN S., KROEZE C., OENEMA O., VELTHOF G., ZHANG F. Alarming nutrient pollution of Chinese rivers as a result of agricultural transitions. Environ. Res. Lett. 11 (2), 1748, 2016.

35. NORTHINGTON R.M., HERSHEY A.E. Effects of stream restoration and wastewater treatment plant effluent on fish communities in urban streams. Freshwater Biol. 51 (10), 1059, 2006.

36. JAVED M., USMANI N. Assessment of heavy metal $(\mathrm{Cu}$, $\mathrm{Ni}, \mathrm{Fe}, \mathrm{Co}, \mathrm{Mn}, \mathrm{Cr}, \mathrm{Zn}$ ) pollution in effluent dominated rivulet water and their effect on glycogen metabolism and histology of Mastacembelus armatus. SpringerPlus. 2, 390, 2013.

37. MARCOGLIESE D.J., BLAISE C., CYR D., DE LAFONTAINE Y., FOURNIER M., GAGNÉ F., GAGNON C., HUDON C. Effects of a major municipal effluent on the St. Lawrence River: A case study. Ambio. 44 (4), $257,2015$.

38. SONTHIPHAND P., CEJUDO E., SCHIFF S.L., NEUFELD J. D. Wastewater Effluent Impacts AmmoniaOxidizing Prokaryotes of the Grand River, Canada. Appl. Environ. Microbiol. 79 (23), 7454, 2013.

39. YE X., GUO X., CUI X., ZHANG X., ZHANG H., WANG M. K., QIU L., CHEN S. Occurrence and removal of endocrine-disrupting chemicals in wastewater treatment plants in the Three Gorges Reservoir area, Chongqing, China. J Environ Monit. 14 (8), 2204, 2012.

40. SHAMUYARIRA K.K., GUMBO J.R. Assessment of heavy metals in municipal sewage sludge: A case study of Limpopo province, South Africa. Int. J. Environ. Res. Public Health. 11 (3), 2569, 2014

41. HUSSAIN S.M., JAVED M., ASGHAR S., HUSSAIN M., ABDULLAH S., RAZA S.A., JAVID A. Studies on growth performance of metals mixture stressed Cirrhina mrigala in earthen ponds. Pak. J. Agri. Sci. 47 (3), 263, 2010.

42. SHIN K.W., KIM S., KIM J., HWANG S.D. KANG J. Toxic effects of ammonia exposure on growth performance, hematological parameters, and plasma components in rockfish, Sebastes schlegelii, during thermal stress. Fish. Aqua. Sci. 19 (44), 2016.

43. IWANOVICZ L.R., BLAZER V.S., GUY C.P., PINKEY A.E., MULLICAN J.E., ALVAREZ D.A. Reproductive health of bass in the Potomac, USA, Drainage: Part 1. Exploring the effects of proximity to wastewater treatment plant discharge. Environ. Toxicol. Chem. 28 (5), 1072, 2009.

44. TETREAULT G.R., BENNET C.J., SHIRES K., KNIGHT B., SERVOS M.R., MCMASTER M.E. Intersex and reproductive impairment of two species wild fish exposed to multiple municipal wastewater discharges. Aquat. Tox. 104 (3-4), 278, 2011.

45. HEATH A.G. Water Pollution and Fish Physiology. 2nd ed.; CRP Press. 1995.

46. MAIER D., BLAHA L., GIESI J.P., HENNEBERG A., KÖHLER H.R., KUCH B., OSTERAUER R., PESCHKE K., RICHTER D., SCHEURER M., TRIEBSKORN R. Biological plausibility as a tool to associate analytical data for micropollutants and effect potentials in wastewater, surface water, and sediments with effects in fishes. Water Res. 72, 127, 2014.

47. MOHANTY M., ADHIKARI S., MOHANTY P., SARANGI N. Effect of waterborne zinc on survival, growth, and feed intake of Indian major carp, Cirrhinus mrigala (Hamilton). Water Air Soil Pollut. 201 (1-4), 3, 2009.

48. PYLE G.G., RAJOTTE J.W., COUTURE P. Effects of industrial metals on wild fish populations along a metal contamination gradient. Ecotoxicol. Environ. Saf. 61 (3), 287, 2005.

49. DESJARDINS L.M., HICKS B.D., HILTON J. W. Iron catalyzed oxidation of trout diets and its effect on the growth and physiological response of rainbow trout. Fish Physiol. Biochem. 3 (4), 173, 1987.

50. GRIZZLE J.M., HOROWITZ S.A., STREHNGT D.R. Caged fish as monitors of pollution: Effects of chlorinated effluent from a wastewater treatment plant. Jawra. 24 (5), 951, 1988. 
51. FOATA J., QUILICHINI Y., TORRES J., PEREIRA E., SPELLA M.M., MATTEI J., MARCHAND B. Comparison of arsenic and antimony contents in tissues and organs of brown trout caught from the river Presa polluted by ancient mining practices and from the river Bravona in Corsica (France): A Survey Study. Arch. of Environ. Contam. Toxicol. 57 (3), 581, 2009.

52. MAGER E.M., EBAUGH A.J., BRIX K.V., RYAN A.C. GROSELL M. Influences of water chemistry on the acute toxicity of lead to Pimephales promelas and Ceriodaphnia dubia. Comp. Biochem. Physiol. 153 (1), 82, 2010.

53. VERA-CANDIOTI J., SOLONESKI S., LARRAMENDY M.L. Acute toxicity of chromium on Cnesterodon decemmaculatus (Pisces: Poeciliidae). Theoria. 20 (1), 81, 2011.

54. TEAD J.P., HOOD J.M., WHELAN N.V., KENDRICK M.R., NELSON D., HANNINEN A.F., DEMI L.M. Coupling of dietary phosphorus and growth across diverse fish taxa: a meta-analysis of experimental aquaculture studies. Ecology. 95 (10), 1768, 2014.

55. COUTURE P., KUMAR P.R. Impairment of metabolic capacities in copper and cadmium contaminated wild yellow perch (Perca flavescens). Aquat. Toxicol. 64 (1), 107, 2003.

56. PIERRON F., BOURRET V., ST-CYR J., CAMPBELL P. G.C. BERNATCHES L., COUTURE P. Transcriptional responses to environmental metal exposure in wild yellow perch (Perca flavescens) collected in lakes with differing environmental metal concentrations $(\mathrm{Cd}, \mathrm{Cu}, \mathrm{Ni})$. Ecotoxicology. 18 (5), 620, 2009.

57. BRIGHTONE K., NYIRENDA J. Assessing the bioaccumulative impact of four heavy metals on the endocrine system of Tilapia rendalli fish species in the Kafue River. Annual Res. Review in Biol. 9 (4), 1, 2016.

58. CAMPBELL H.A., HANDY R.D., SIMS D. W. Increased metabolic cost of swimming and consequent alterations to circadian activity in rainbow trout (Oncorhynchus mykiss) exposed to dietary copper. Can. J. Fish. Aquat. Sci. 59 (5), 768, 2002.

59. JEZIERSKA B., ŁUGOVSKA K. WITESKA M. The effects of heavy metals on embryonic development of fish. Fish Physiol. Biochem. 35 (4), 625, 2009.

60. MCKINLEY A.C., MISKIEWICZ A., TAYLOR M.D., JOHNSTON E.L. Strong links between metal contamination, habitat modification and estuarine larval fish distributions. Environ. Poll. 159 (6), 1499, 2011.

61. WEIS J.S., CANDELMO A. Pollutants and fish predator/ prey behavior: A review of laboratory and field approaches. $58(1), 9,2012$.

62. IWASAKI Y.Y., KAGAVA T., MIYAMOTO K., MATSUDA $\mathrm{H}$. Effects of heavy metals on riverine benthic macroinvertebrate assemblages with reference to potential food availability for drift-feeding fishes. Environ. Toxicol. Chem. 28 (2), 354, 2009.

63. COUTURE P., DUTIL J.D., GUDERLEY H. Biochemical correlates of growth and condition in juvenile Atlantic cod (Gadus morhua) from Newfoundland. Can. J. Fish. Aquat. Sci. 55 (7), 1591, 1998.

64. NEWMAN M.C., MITZ S.V. Size dependence of zinc elimination and uptake from water by mosquitofish Gambusia affinis (Baird and Girard). Aquat. Toxicol. 12 (1), 17, 1988

65. VARDY D.W., OELLERS J., DOERING J.A., HOLLERT H., GIESY J.P. Sensitivity of early life stages of white sturgeon, rainbow trout, and fathead minnow to copper. Ecotoxicology 22 (1), 139, 2013.
66. LIANG Y.R., CHEUNG Y.H., WONG M.H. Reclamation of wastewater for polyculture of freshwater fish: bioaccumulation of trace metals in fish. Water Res. 33 (11), 2690, 1999.

67. RAJKOWSKA M., PROTASOWICKI M. Distribution of metals $(\mathrm{Fe}, \mathrm{Mn}, \mathrm{Zn}, \mathrm{Cu})$ in fish tissues in two lakes of different trophy in Northwestern Poland Environ. Monit. Assess. 185 (4), 3493, 2013.

68. AL-GHANIM K.A.A, ABDELATTY M., ABDELFATTAH L., MAHBOOB S. Differential uptake of heavy metals by gill, muscles and liver of four selected fish species from Red sea. Pakistan J. Zool. 47 (4), 1031, 2015.

69. FATHI H.B., OTHMAN A.G., MAZLAN A., ARSHAD A. AMIN S.M.N., SIMON K.D. Trace metals in muscle, liver and gill tissues of marine fishes from Mersing, eastern coast of peninsular Malaysia: Concentration and assessment of human health risk. AJAVA Asian J. Anim. Vet. Adv. 8 (2), 227, 2013.

70. DAMODHARAN U., REDDY M.V. Heavy metal bioaccumulation in edible fish species from an industrially polluted river and human health risk assessment. Arch. Pol. Fish. 21 (1), 19, 2013.

71. STANEK M., ANDRZEJEWSKI W., MAZURKIEWICZ J., JANICKI B., CYGAN-SZCZEGIELNIAK D., ROŚLEWSKA A., STASIAK K., WASZAK I. Seasonal investigation of selected mineral contents in meat, gills, and liver of perch (Perca fluviatilis L.) from western Poland. Pol. J. Environ. Stud. Vol. 25 (1), 301, 2016.

72. IQBAL A., TABINDA A.B., YASAR A., MAHFOOZ Y. Heavy metal uptake and toxicity in tissues of commercially important freshwater fish (Labeo rohita and Wallago attu) from the Indus river, Pakistan Pol. J. Environ. Stud. 26 (2), 627, 2017

73. ORATA F., BIRGEN F. Fish tissue bio-concentration and interspecies uptake of heavy metals from waste water lagoons. J. Pollut. Eff. Cont. 4 (2), 2016.

74. AUDET D., COUTURE P. Seasonal variations in tissue metabolic capacities of yellow perch (Perca flavescens) from clean and metal-contaminated environments. Can. J. Fish. Aquat. Sci. 60 (3), 269, 2003.

75. KRAEMER L., CAMPBELL P.G.C., HARE L. Seasonal variations in hepatic $\mathrm{Cd}$ and $\mathrm{Cu}$ concentrations and in the sub-cellular distribution of these metals in juvenile yellow perch (Perca flavescens).Environ. Pollut. 142 (2), 313, 2006.

76. BAHNASAWY M., KHIDR A., DHEINA N. Assessment of heavy metal concentrations in water, plankton, and fish of Lake Manzala, Egypt. Turk. J. Zool. 35 (2), 271, 2011.

77. NAMIESNIKA J., RABAJCZYKB A. The speciation and physico-chemical forms of metals in surface waters and sediments. Chem. Spec. Bioavailab. 22 (1), 2047, 2010.

78. KOFFI K.M., COULIBALY S., ATSE B.C., KOUAMELAN E.P. Survey of heavy metals concentrations in water and sediment of the estuary Bietry Bay, Ebrie Lagoon, Cote d'ivoire. Int. J. Res. Earth Environ. Sci. 1 (1), 2311, 2014.

79. DRIEDGER K., WEBER L.P., PICKWOOD C.J., DUBE M.G., JANZ D.M. Growth and energy storage in juvenile fathead minnows exposed to metal mine waste water in simulated winter and summer conditions. Ecotoxicol. Environ. Saf. 73 (5), 727, 2010.

80. WANG Y., HONGYUAN W., YIN Z., NIU J., SHEN $Z$. Distribution and transformation of nutrients in largescale lakes and reservoirs: the Three Gorges Reservoir (Advanced topics in science and technology in China). Springer-Verlag. 2013.

81. ZAYED M.A., ELDIEN F.A.N. Comparative study of seasonal variation in metal concentrations in river 
Nile sediment, fish, and water by atomic absorption spectrometry. Microchem. J. 49 (1), 27, 1994.

82. ÇOĞUN H.Y., YÜZEREROĞLU T.A., FIRAT O., GÖK G., KARGIN F. Metal concentrations in fish species from the northeast Mediterranean Sea. Environ. Monit. Assess. 121 (1-3), 431, 2006

83. SETH H., GRÄNS A., SANDBLOM E., OLSSON C., WIKLANDER K., JOHNSSON J.I., AXELSSON M. Metabolic scope and interspecific competition in sculpins of Greenland are influenced by increased temperatures due to climate change. 8 (5), 2013.

84. TOLONEN A., LAPPALAINEN J., PULLIAINEN E. Seasonal growth and year class strength variations of perch near the northern limits of its distribution range. J. Fish Biol. 63 (1), 176, 2003.

85. HASHIM R., SONG T.H., MUSLIM N.Z., YEN T.P. Determination of heavy metal levels in fishes from the lower reach of the Kelantan River, Kelantan, Malaysia. Trop Life Sci. Res. 25 (2), 21, 2014.

86. IGWEGBE A.O., NEGBENEBOR C.A., CHIBUZO E.C., BADAU M.H. Effects of season and location on heavy metal contents of fish species and corresponding water samples from Borno State of Nigeria. Glo. Adv. Res. J. Med. Med. Sci. 3 (3), 64, 2014.
87. JOHANSSON K., BRINGMARK E., LINDEVALL L., WILANDER A. Effects of acidification on the concentrations of heavy metals in running waters in Sweden. Water Air Soil Pollut. 5 (2), 779, 1995.

88. MZIMELA H.M., WEPENER V., CYRUS D.P. Seasonal variation of selected metals in sediments, water and tissues of the groovy mullet, Liza dumerelii (Mugilidae) from the Mhlathuze Estuary, South Africa. Mar. Pollut. Bull. 46 (5), 659, 2003.

89. EUROPEAN COMMISSION. Commission Regulation (EC) No. 629/2008 of 2 July 2008, Amending Regulation (EC) No. 1881/2006 setting maximum levels for certain contaminants in foodstuffs, Offic. J. Europ. Union L173. 2008.

90. FAO, WHO. Report of the fifth session of the Codex Comitee on Contaminats in Foods. The Hague, The Netherlands, 21-25 March 2011, Joint FAO/WHO food standards programme, Codex Alimentarius Commission, REP11/CF. 2011.

91. BREY T. Conversion factors for Perca fluviatilis. Alfred Wegener Institute, Bremerhaven. http://www.fishbase.org/ summary/biomass.php?id=358 (accessed on 20.12.2017). 
